\title{
Student learning independence using the application of the recitation method during online learning through the Google Classroom App
}

\section{Riawati Azizah}

Sunan Ampel State Islamic University Surabaya

riawati.azizah96@gmail.com

DOI: 10.18326/attarbiyah.v6i1.47-60

Submitted:

31 March, 2021
Accepted:

6 August, 2021
Published:

11 August, 2021

\begin{abstract}
In an effort to reduce increasing number of Covid-19 spread, currently, majority of students from early childhood education to universities are undergoing online learning. There are various learning management systems (LMS) as well as social media digital platforms that can be utilized by teachers and students to carry out online learning, one of which is Google Classroom. By applying the recitation or assignment method through Google Classroom, it is found that student learning independence has not been formed optimally. This research aims to describe how student learning independence is viewed from the application of the assignment method in the specific case of Islamic education subject during online learning through Google Classroom. This is descriptive qualitative research which collects data from interviews with six subjects who regularly use Google Classroom application as a learning medium and assignments. The six subjects interviewed consist of teachers and college students. This study shows that Google Classroom is considered quite effective as an assignment medium because it could be accessed anywhere and anytime and saved storage. However, in terms of independence student skill, it is tend to not work as expected. Therefore, more efforts are required by the teachers to give students motivation and increase the awareness to develop independent learning skills of students.
\end{abstract}

Keywords: Google Classroom, Recitation Method, Independent Learning 


\section{INTRODUCTION}

COVID-19, which initially hit China, has affected the whole world, including Indonesia. There have been many policies made by the government and affect our world of education today. The reason is that with the implementation of regional quarantine, all educational institutions from early childhood education to higher education still eliminate learning in the classroom. Instead, the learning method is carried out online. This is supported by Circular Letter No. 4 of 2020 concerning the Implementation of Educational Policies in the Emergency Period of the Spread of Coronavirus Disease (COVID-19) issued by the Ministry of Education and Culture (Kemendikbud) and signed by the Minister of Education and Culture, Nadiem Makarim, on March 24, 2020. The principle applied in the policy during the COVID-19 pandemic is the health and safety of students, teachers, educational personnel, families, and the community is a top priority in setting learning policies. This online learning is considered by the government as the only solution to ensure the continuity of the teaching and learning process from elementary school to university level continues (Zukifli, et al., 2021).

Online learning is implemented in various ways by teachers in the midst of school closures in various regions as a result of the COVID-19 being increasingly widespread today. Long-distance education has been started in 1883 and continues to grow along with advances in science and technology. Its development was quite slow to go into the next generation of distance education which began with the use of audio/radio and video/television in the 1950-1990s. The fact shows that since the 1990s to this moment, electronic technology, both computer-mediated and electronic-assisted learning have been used (Prawiradilaga, 2013).

The contribution of technological developments to the world of education allows for the dissemination of information widely, evenly, quickly, uniformly and integrated with one another. The presentation of teaching materials in a logical, scientific and systematic manner will be able to support, complete and explain the concepts and principles of the subject matter being discussed. The development of technology helps teachers in realizing a more effective, efficient, and productive teaching and learning process in accordance with educational goals and in accordance with the needs and demands of students. With technology, it is possible to present material more attractively by utilizing various learning resources (Nurdin, 2016). 
As a consequence of the separation of place and time between teachers and students, relevant media are needed, both print, audio, video and other technologies allowing two-way communication. One model for implementing distance learning is to use a fully online model in which all learning interactions and delivery of teaching materials occur online (Prawiradilaga: 2013). The fully online model is very suitable to be applied during pandemics like today. However, the implementation is considered less optimal and shows a lack of independence among teachers and students themselves to fully adapt to online learning. So far, many schools have implemented an online method for assignments. The recitation or assignment method is given through various apps, such as WhatsApp grup, Google Classroom, and others.

One of the apps which are often used by teachers in conducting online learning is Google Classroom, including for Islamic Religious Education (PAI) class. Google Classroom is an online learning application which can be used for any scope of education without having to meet face-to-face in the learning process and collecting assignments paperlessly. This software has been introduced as a part of Google Apps for Education (GAFE) since August 12, 2014 (Gunawan, et.al., 2016). Google Classroom is an application allowing the creation of classrooms in cyberspace in a simple, easy-tounderstand and easy-to-use manner.

The Google Classroom app does not require a special installation process. Through this application with various features it has, it makes it easier for teachers and students to carry out online learning more deeply. This is because teachers and students can give assignments, collect assignments, distribute assignments, and even directly assess assignments without being bound by the lesson time limit. In giving assignments, teachers do not need to worry if there is a violation from their students because teachers are given access by Google Classroom to manage assignments sent so students can only view, edit, or comment. Through Google Classroom, teachers can also monitor the progress of their students' learning, whether the students are diligent in working on and collecting the assignments given or not.

Assignments are considered effective for distance learning. However, the consequence is that the delivery of concepts regarding PAI lessons cannot run well as they are usually applied in the classroom. The steps of face-to-face learning in the classroom usually follow certain stages in the cognitive domain scheme $\mathrm{C} 1$ to $\mathrm{C} 6$ or known as 
Bloom's taxonomy. The cognitive domain becomes a guide in delivering lessons to students starting with the delivery of knowledge, then proceeding to understanding, applying, analyzing, evaluating, and finally creating (Muhaimin, 2007). In face-to-face learning in the classroom, there will be a delivery of the learning concept and its objectives first. Then learning is continued until understanding and development. Unfortunately, these stages are considered not going well in online learning today.

During online learning, teachers can provide explanations of subject matter using videos, audio, or slides which can be uploaded and shared with students through various selected online learning applications, such as Google Classroom, WhatsApp grup, and others. Sometimes there are some students who still have difficulty in understanding the explanation, either in the form of video, audio, or slides because it is different from when they do it in the classroom where students can directly ask and discuss if there is material they do not understand. In this case, the recitation method through the Google Classroom app during online learning is expected to facilitate and ease the burden on students in understanding subject matter which cannot be delivered directly face to face by their teachers. Thus, students can better understand the explanation of the subject matter given by their teacher by doing the practice questions assigned to the students independently.

In applying the recitation or assignment method, there are several things which need to be considered and fulfilled by the teacher, including:

1. The material from the questions given as assignments to students must be appropriate and related to the material which has been studied so that students can complete their tasks well, as well as so that students are able to connect the task with the material that has been obtained in order to further strengthen their understanding.

2. The teacher must give questions to students by measuring and estimating the abilities of students so that students can complete tasks according to their abilities and intelligence.

3. The teacher must instill in the students that the task is the responsibility of the students to the teacher so it must be done by the students themselves. It is permissible to ask for help from others but not entirely or to provide answers to these questions directly. 
4. In giving assignments to students, it must be clear what type of assignments are given so that students can complete their assignments confidently without any doubts (Zakiah, et al., 2009).

In the learning process, each student is directed to become students who have independence in learning. It is reinforced to students that it is students who need knowledge, not teachers, so students themselves will be at a loss if they do not pay attention or take various initiatives themselves to gain as much knowledge as possible from their teachers. Teachers also need to motivate students to be enthusiastic in learning and be able to complete the tasks given by the teacher independently and as well as possible. Teachers are the first to improve the quality of education through the teaching and learning process in schools. As the main actor in the learning process, the learning and guidance provided by the teachers to their students is the door that will lead to the success of students (Lempe \& Hendrik, 2018). In the learning process, each student is expected to have independence in learning so they can start learning on their own initiative without having to wait for orders.

However, the learning independence of students during online learning has not yet been formed as expected. There are still many students who lack confidence in their own abilities, students who always ask to be directed by the teacher in learning activities, students who have not been able to do assignments independently so that there are still many who often cheat or rely on their friends to complete the assigned tasks, students who do not have responsibilities in carrying out their duties, and students who always want to quickly end their teaching and learning activities. In addition, the activities carried out by students in online learning should also allow students to get used to being independent in following various stages of learning activities. Independent learning is an important factor in determining student success in the lecture process. Students are required to be able to take responsibility for making decisions related to their learning process and have the ability to carry out the decisions they make (Sudiana et al., 2017). However, the various phenomena occurring above illustrate that the points of independence in students have not been formed optimally.

The importance of forming student learning independence has been discussed in an article uploaded on the Indonesia Approach Education website in the article concerning the importance of forming learning independence during a pandemic. The 
article explains that due to the limitations of space and time in online learning as it is today, the independence of students to learn responsibly and without orders needs to be formed and directed (Indonesia Approach Education, 2020).

Research on the importance of learning independence for students has also been carried out by Suid and his colleagues in their research on the analysis of student independence in the learning process at the elementary school level (Suid, Tursinawati, \& Alfiati Syafrina, 2017). The results of the study indicate that there are still many problems occurring related to student independence which has not been formed optimally.

The finding shows that learning independence is important for students to have in the teaching and learning process, especially with the implementation of online learning as it is today. If the condition of learning independence of students which has not been formed optimally like this continues to be left without any further action, it is feared that it will affect the learning process and also student learning outcomes. Therefore, an effort is needed to increase motivation in forming learning independence in students.

\section{METHODS}

This research belongs to qualitative-descriptive research. This type of qualitative descriptive research is a method utilizing qualitative data and is explained descriptively. This descriptive qualitative research examines forms, activities, characteristics, changes, relationships, similarities, and differences with other phenomena (Sukmadinata, 2007). This research is conducted with the aim of obtaining an overview of the effect of applying the assignment method in the specific case of Islamic education subject based on Google Classroom for teachers and students during online learning.

The data collecting technique in this research is through interviews and observations. In the research, interviews are conducted with teachers and students. In addition to teachers from elementary, secondary, and upper education levels, there are also students from universities who become the informants in this research. So from the interviews conducted with these informants, it is hoped that the researcher can find the students' learning independence by applying the recitation method during online learning at two levels; the school level and the university level. Given the assumption that university students, which in terms of age and responsibility, should have better learning 
independence skills when compared to students at the school level. Then observations are made by developing observations based on developments occurring in the field. In this case, the observations conducted are non-participant because the observer does not participate and take part in the life of the party being observed (Riyanto, 2001).

\section{RESULT AND DISCUSSION}

There are two subject activities in the teaching and learning process; teacher activities and student activities. Learning activities produce interaction as a process in order to achieve the learning objectives to be achieved. Learning methods and media are very important components and should be considered during the learning process in an effort to achieve the desired learning objectives.

According to Wina Sanjaya, the learning method is a component that will determine success in achieving learning objectives (Sanjaya, 2008). Thus, it is necessary for teachers to determine learning methods which are appropriate to the circumstances and abilities of students. As in a situation in which all learning processes must be carried out online, teachers also need to determine methods which are deemed suitable and appropriate to be applied in the learning process, which even though they have to study at home, students will still be active in learning. In a way like a teacher applies the recitation method in online learning using Google Classroom, an app which is now in great demand by teachers and students during online learning.

According to Ambarjaya, the recitation or assignment method is a method of presenting material in which the teacher gives certain tasks so that students carry out learning activities (Ambarjaya, 2012). A similar opinion is also conveyed by Nana et al. in the journal article by Melania and Fahmi, stating that the recitation or assignment method is a method of presenting learning materials in which the teacher gives certain tasks to students so that students carry out learning activities and provide reports as a result of the tasks they have done. This method refers to the application of learning by doing. The purpose of the recitation method is also that after students do the assignments, students are required to report their work to the teacher to be evaluated and accounted for before students do the next assignments (Melania \& Fahmi, 2016). 
Learning strategies must be able to encourage student learning independence and activities (Susanto and Rahmatullah, 2020) such as by applying the recitation method during online learning through Google Classroom. This can stimulate the independence and learning activities of students who not only follow and listen to the material provided by the teacher through slides and videos but can also encourage students to connect the material they have learned with the assignment, as well as seek reinforcement or additional information from the internet regarding the related material independently.

Independence is one of the attitudes which can determine student success in learning, so it is important to have this independent attitude for anyone who wants to be successful in life (Aziz \& Basry, 2017). Independent learning is a learning activity carried out by individuals with the freedom to determine and manage their own teaching materials, time, place, and utilize various learning resources needed. More emphasis on student internal factors, according to Suhendri, student independence is a learning activity carried out by students without relying on help from other people, both friends and teachers in achieving learning goals, in this case such as mastering the material and knowledge well with the students' own awareness and being able to apply the knowledge which has been obtained in solving problems in everyday life (Suhendri: 2010). According to Gea, an individual is said to be independent if they have the following five characteristics: 1) self-confidence, 2) able to work alone, 3) mastering skills and competence based on their work, 4) respecting time, and 5) being responsible (Gea et. al., 2003).

The use of Google Classroom as a learning medium is quite attractive, especially during the current COVID-19 pandemic. To find out the effect of the recitation or assignment method through Google Classroom on student learning independence, the researcher interviewed six subjects using Google Classroom consisting of three teachers and three students learning Islamic education subject.

The first subject is a teacher at a private elementary school in Surabaya. Subject 1 teaches Reading and Writing the Qur'an. According to subject 1, online learning affects the understanding of students who need special attention. In face-to-face learning, students can understand the material in one meeting but online learning requires more than one meeting. However, choosing Google Classroom as a medium of learning and 
assignments is considered quite beneficial because it is easily accessible and the facilities provided in Google Classroom are quite complete. The posted material can be seen even if new members join, have a sign that they have or have not submitted assignments, and assignments can be immediately given a grade. In addition, subject 1 also feels that it is easier because Google Classroom provides many choices in assignment submissions and the data is still stored even though it is not downloaded as long as it is not deleted from Google Classroom.

Various features in Google Classroom make it easier for Subject 1 as a teacher. However, Google Classroom still has shortcomings, such as there are still students who have difficulty creating accounts and not all students are on time to do the assignments that have been given. However, the students taught by subject 1 admit that learning and assignments using Google Classroom are quite fun (Nafisa, 17 June 2020).

The second subject is a teacher of Islamic Religious Education (PAI) at a private elementary school in Surabaya. Subject 2 started using Google Classroom as a teaching medium since the regional government issued a circular letter concerning distance learning for elementary school students. Similar to the first subject, subject 2 chooses to use Google Classroom because the many features provided make it easier to categorize assignments. However, subject 2 has more difficulties because the students being taught are still at an early age so that learning independence has not been formed in students.

Subject 2 admit that not all students read the task instructions carefully, so there are still many who ask the teacher and their friends about the assignments which have been given. When students are familiar with one of the task models and learning resources provided by the teacher, and then the assignment format is changed and students are asked to look for other learning resources supporting the learning process, there are still some students who complain and only rely on what is given by the teacher (Rachma, 18 June 2020).

The third subject is a teacher at a Vocational High School in Magetan. Subject 3 has also only used Google Classroom as a medium of learning and assignments since the implementation of online learning as an effort to prevent the spread of COVID-19. Subject 3 chooses Google Classroom because it is considered widely used and all students can join based on their respective classes. Subject 3 admits that the assignment through Google Classroom is more effective because it can be directly assessed. In addition, teachers can also upload videos or slides of teaching materials. 
The obstacle experienced by subject 3 while using the Google Classroom with the assignment method is the delay of students in collecting the assignments which have been given. Subject 3 explains there are still many students who need to be reminded about the deadline for collecting assignments which have been set. On the due date of the assignment, there are still some students who have not submitted their assignments, even more than one or two days later from the time set by the teacher. Because of this, subject 3 also applies a different scoring system for students who are on time in collecting assignments with students who are late in submitting assignments (Sartini, 13 June 2020).

Furthermore, the researcher also interviewed undergraduate students at one of the universities in Malang. Subject 4 admits that lectures using Google Classroom are quite organized because weekly assignments, materials, quizzes, questions and answers could be done in one place. In addition, the lecturer gives a deadline for submitting assignments so that students do not need to be reminded again. Subject 4 argues that the assignment method through Google Classroom can make students more independent regarding deadlines for collecting and completing assignments if students have awareness and responsibility for themselves. But as known by subject 4 , it turns out that there are still one or two students who still rely on friends in completing their assignments, which means that in this case, there are still students who have not done their assignments independently. According to subject 4, the assignment through Google Classroom is quite effective but for the delivery of material, it is not clear (Aulia, 13 June 2020).

A similar thing is also experienced by Subject 5 . The fifth subject is a student at a university in Surabaya. Subject 5 feels that lectures using Google Classroom are quite effective because the Google Classroom application is relatively light and can be accessed via mobile phone. Each meeting has its own space to facilitate interaction between students and lecturers. Subject 5 says that setting a deadline for collecting assignments through Google Classroom is enough to discipline students to submit assignments on time. Students are also quite independent in doing assignments individually without cheating on each other (Ayu, 20 June 2020).

The researcher also interviewed a new student at a university in Yogyakarta. From the beginning of college until now, subject 6 has never participated in face-to-face learning activities on campus because of online learning orders which are currently 
happening. Subject 6 also uses Google Classroom as a medium of learning with their lecturers because for subject 6 and other college friends, they think that the lecturer is very strict and applies the rules that if someone is late in collecting their assignments, the assignments will not be accepted. Therefore, this makes students more independent and reaches the deadline for collecting assignments as determined by the lecturer (Maulida, 21 June 2020).

In the application of the recitation method through Google Classroom, both teachers and students find it easy to carry out online learning. On the other hand, from the results of interviews with several subjects as described above, it can be concluded that in general, student learning independence during online learning is still not optimally formed. There are still many students who have not been able to collect assignments according to the deadline which has been given, there are still many students who are accustomed to the models and learning resources which have been provided by the teacher so that when they are asked to find other supporting learning resources they still complain, and there are students who still rely on friends in completing their assignments so that they have not been able to complete their assignments independently.

Learning is not just a process of remembering something, it is deeper than that as it is also about gaining experience. Learning outcomes are not just mastery of the knowledge nor training but also changes in behavior (Hamalik, 2007). As the achievement of the learning process, the independent character is influenced by several factors. Ali and Asrori suggest that there are four factors which can affect student independence including genes or parental descent, parenting patterns, the education system in schools, and also the life system occurring in society (Ali and Asrori, 2005).

Therefore, some efforts to develop the learning independence of students during the teaching and learning process which can be done by the teacher are necessary, including:

1. Creating active participation and involvement of students in learning by providing motivation and rewards when students can complete assignments independently and on time.

2. Developing democratic learning which allows students to feel appreciated during the teaching and learning process. 
3. Encouraging the freedom of students in exploring their environment and fostering curiosity in students.

4. Positive and open acceptance of all abilities possessed by students without discrimination.

5. Establishing a good relationship with students so that they will feel comfortable learning with the teacher instead of feeling afraid or depressed during learning.

\section{CONCLUSION}

One of the online learning apps which are widely used by teachers in carrying out the teaching and learning process during online learning is Google Classroom. Many teachers choose Google Classroom because it tends to be broad in scope so that a series of learning activities can be carried out using the app. Besides, by using Google Classroom, students can be more focused on each class. Since the learning system in Google Classroom is made in the form of classes, it makes the teachers and students interact fully and more easily in each of these classes so that the learning and assignments given feel more effective. With the application of the assignment model, it is hoped that students can better understand the explanation of the subject matter given by their teacher by doing the practice questions assigned to the students independently.

However, what is seen in the field shows that the learning independence of students during online learning has not been formed as expected. Even the learning independence of college students, which in terms of age and responsibility is expected to be more independent in learning, has not been optimally formed. There are still many students who lack confidence in their own abilities, students who always ask to be directed by the teacher in learning activities, students who have not been able to do assignments independently so there are still many who often cheat or rely on their friends to complete the tasks given, students who do not have the responsibility in finishing assignments, and students who always want to quickly end their teaching and learning activities.

The various phenomena occurring above illustrate that the points of independence in students have not been formed optimally. There are many factors influencing the independent attitude possessed by students. So it takes some efforts which can be done by the teacher in directing the creation of independent learning in students so that learning independence can be formed optimally and with full awareness of the students themselves. 


\section{REFERENCES}

Ali, M. \& M. Asrori. (2005). Psikologi Remaja: Perkembangan Peserta Didik. Jakarta: PT Bumi Aksara.

Ambarjaya, B. (2012). Psikologi Pendidikan dan Pengajaran (Teori dan Praktik). Yogyakarta: CAPS.

Aziz, A. \& Basry. (2017). Hubungan Antara Kompetensi Guru dan Kepercayaan Diri dengan Kemandirian Siswa SMP N 2 Pangkalan Susu. Jurnal Pshycomutiara, 1 (1). 15-29

Darajat, Z. et. al. (2009). Ilmu Pendidikan Islam. Jakarta: Bumi Aksara.

Gea, A.A. et al. (2003). Character Building 1 Relasi Dengan Diri Sendiri (edisi revisi). Jakarta: PT Elex Media Komputindo.

Gunawan, F.I., \& Stefani G. S. (2016). Pengembangan Kelas Virtual dengan Google Classroom dalam Keterampilan Pemecahan Masalah Topik Vektor Pada Siswa SMK untuk Mendukung Pembelajaran. Prosiding Seminar Nasional Etnomatnesia, 340-348.

Hamalik, O. (2007). Dasar-dasar Pengembangan Kurikulum. Bandung: PT Remaja Rosdakarya.

Indonesia Approach Education. (2020). https://www.ia-education.com/2020/07/09/ pentingnya-membentuk-kemandirian-belajar-anak-di-masa-pandemik/.

Lempe, T. \& Hendrik P. T. (2018). "Peran Guru dalam Meningkatkan Kemandirian Belajar Peserta Didik Kelas V SD Inpres Samberpasi." Jurnal Metodik Didaktik 14 (1).

Melania, R.A.I. \& Fahmi W. (2016). Penerapan Metode Resitasi dalam Pembelajaran Keterampilan Menulis Bahasa Jerman Kelas XI Bahasa SMA 13 Negeri Surabaya. Laterne (5) 2. 1-7.

Muhaimin. (2007). Pengembangan Kurikulum Pendidikan Agama Islam. Jakarta: Raja Grafindo Persada.

Nurdin, A. (2016). Inovasi Pembelajaran Pendidikan Agama Islam Era Information and Communication Technology. TADRIS, 11(1): 49-64.

Prawiradilaga, D.S. (2013). Mozaik Teknologi Pendidikan: E-Learning Edisi Pertama. Jakarta: Kencana. 
Riyanto, Y. (2001). Metodologi Penelitian Pendidikan. Surabaya: Penerbit SIC.

Sanjaya, W. (2008). Strategi Pembelajaran Berorientasi Standar Proses Pendidikan. Jakarta: Kencana Prenada Media.

Sudiana, R., Abdul, F. and Etika, K. (2017). Kemandirian Belajar Mahasiswa Melalui Pembelajaran Berbasis Virtual Class. JPPM (Jurnal Penelitian Pendidikan Matematika, 10 (1). 74-80 DOI: http://dx.doi.org/10.30870/jppm.v10i1.1292

Suhendri, H. (2010). Pengaruh Kecerdasan Matematis Logis dan Kemandirian Belajar Terhadap Hasil Belajar Matematika. Formatif: Jurnal Ilmiah Pendidikan MIPA, (1) 1.29-39 DOI: http://dx.doi.org/10.30998/formatif.v1i1.61

Suid, T. \& Alfiati S. (2017). Analsisis Kemandirian Siswa Dalam Proses Pembelajaran Di Kelas III SD Negeri 1 Banda Aceh. Jurnal Pesona Dasar 1 (5).

Sukmadinata, N.S. (2007). Metode Penelitian Pendidikan. Bandung: PT Remaja Rosdakarya. Susanto, E. P. \& Rahmatullah. (2020). Optimalisasi Pembelajaran Pendidikan Agama Islam Melalui Google Classroom. PIWULANG: JurnalPendidikan Islam, 2 (2). 129. 142. http://dx.doi.org/10.32478/piwulang.v2i2.372

Nurmayanti \& Handy F. (2021). Efektifitas Media Pembelajaran Daring di masa Pandemi Covid-19. EDUMASPUL: Jurnal Pendidikan, 5 (1).71-77 DOI:https://doi.org/ 10.33487/edumaspul.v5i1.1123 